\title{
Environmental Evaluation of Building Materials of 5 Slovak Buildings
}

\author{
Milan Porhincak, Adriana Estokova \\ Technical University of Košice \\ Faculty of Civil Engineering, Institute of Building and Environmental Engineering \\ e-mail: milan.porhincak@tuke.sk, adriana.estokova@tuke.sk
}

\begin{abstract}
Building activity has recently led to the deterioration of environment and has become unsustainable. Several strategies have been introduced in order to minimize consumption of energy and resulting $\mathrm{CO}_{2}$ emissions having their origin in the operational phase. But also other stages of Life Cycle should are important to identify the overall environmental impact of construction sector. In this paper 5 similar Slovak buildings (family houses) were analyzed in terms of environmental performance of building materials used for their structures. Evaluation included the weight of used materials, embodied energy and embodied $\mathrm{CO}_{2}$ and $\mathrm{SO}_{2}$ emissions. Analysis has proven that the selection of building materials is an important factor which influences the environmental profile. Findings of the case study indicated that materials like concrete, ceramic or thermal insulation materials based on polystyrene and mineral wool are ones with the most negative environmental impact.
\end{abstract}

Key words: environmental assessment, environmental profile, embodied energy, embodied $\mathrm{CO}_{2}$

\section{Introduction}

Human activities including construction of buildings which have led to the deterioration of environment have recently become a point of interest of professionals from various branches [1]. After more than 50 years of research the building sector is still responsible for many harmful issues. Pollution of soil, water and air resulting from unsustainable use of massive amount of raw materials are the principal issues of building industry. For example, the construction industry is responsible for depletion of $40 \%$ of stone, gravel, and sand; use of $25 \%$ of wood; and for consumption of $16 \%$ of fresh water every year [2]. The intensive use of energy originating from fossil fuels results in the generation of greenhouse gasses emissions. Contemporary buildings of developed countries are responsible for 1/4-1/2 of total energy used [3]. To mitigate the climate change the reduction of $\mathrm{CO}_{2}$ emission by $50 \%$ by 2050 needs to be achieved [4]. In addition, the requirements on building quality are rising while supplies remain more limited. Many progressive buildings require the use of high amount of materials (e.g. thermal insulation, membranes) or improving of quality of indoor environment involves 
the utilization of hi-tech appliances. To reduce such a strong demand and to minimize the negative impacts, the European Union has issued a number of acts aimed at the reduction of energy consumption by $20 \%$, decrease of $\mathrm{CO}_{2}$ emissions by $20 \%$, and increase of the share of renewable energy resources to 20\%. The Directive on Energy Performance of Buildings requires implementing energy efficiency legislations for new, as well as existing buildings [5, $6]$.

The majority of regulations deal with the usage phase (operational energy and greenhouse gasses emissions). Due to long life span of buildings the usage of buildings is the stage with substantial environmental impact. However, concerning the buildings life cycle, also other aspects are included to identify the overall environmental impact. As universal optimal design does not exist, the individual analysis is necessary [7]. Design of material composition of building in the early stages predefines the future behaviour (usage stage) and thus influences the overall environmental performance [8].

This paper is aimed at analysis of environmental performance of building materials of 5 family houses. Materials of selected buildings were analyzed in terms of amount of used materials, embodied energy and embodied $\mathrm{CO}_{2}$ and $\mathrm{SO}_{2}$ emissions within cradle to gate system boundaries.

\section{Material and methods}

\subsection{Description of the evaluated buildings}

Five similar buildings (family houses) were selected for evaluation of environmental performance of building material. Each single storey building is with a gabled roof, has no basement and is suitable for 3-6 inhabitants. Some of the houses have roofed entrance, terrace, garage or gutter side walk. Areal and volumetric characterization of building consists of the 'total build-up area' (includes the area of house itself, terrace, leeward, gutter sidewalk), 'computing build-up area' (area of house including roofed terrace and leeward), 'total useful area' (area of rooms without walls and pillars, including terrace and leeward), 'computing useful area' (indoor room area without walls and pillars), 'living area' (living floor space) and 'build-up space' (volume of building). Configuration of compared buildings together with areal and cubical size description is presented in table 1.

Table 1: Configuration of assessed buildings

\begin{tabular}{|c|c|c|c|c|c|c|c|c|c|c|c|}
\hline 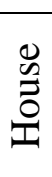 & 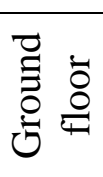 & 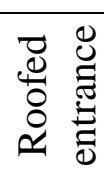 & 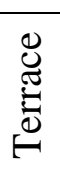 & 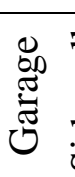 & 童 & 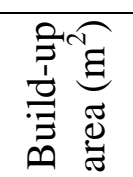 & 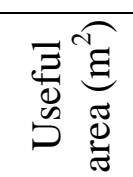 & 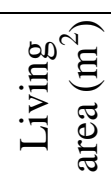 & 光导 & 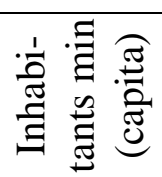 & 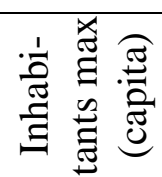 \\
\hline 1 & + & - & - & - & + & 145 & 122.09 & 80.99 & 653.4 & 3 & 6 \\
\hline 2 & + & + & + & - & + & 158.8 & 123.28 & 66.32 & 642.1 & 3 & 6 \\
\hline 3 & + & + & + & - & + & 191.95 & 126.94 & 76.8 & 875.1 & 3 & 5 \\
\hline 4 & + & - & - & - & + & 107.09 & 80.1 & 43.6 & 607.7 & 3 & 4 \\
\hline 5 & + & + & + & + & + & 181.99 & 140.69 & 75.55 & 855.3 & 3 & 6 \\
\hline
\end{tabular}




\subsection{Material composition of the assessed buildings}

In order to illustrate the representative environmental profile of Slovak build-up 5 similar conventional buildings with standard material compositions were selected for the evaluation. The building foundations consisted of concrete on gravel layer. Damp proof course was made of polymer bitumen sheet, bitumen-aluminium sheet or PVC foil. Perforated ceramic bricks or aerated concrete blocks broadly used for masonry walls (external, internal, partitions) of Slovak houses were used in the evaluated buildings [9]. Lintels and bond-beams are designed of reinforced concrete. As ceiling construction materials were used: reinforced concrete, prefab ceramic block on prefab concrete joist or wood. However, for houses with ground floor only (bungalow), where the attic is not habitable the wood is preferred alternative and was used in 3 of 5 houses. Framework of roof is without exception constructed of wood, while roofs weatherproofing consists of wider range of materials (concrete or ceramic tiles, bitumen or metal sheets). Various types of thermal insulation were used for insulation of foundations, floors, walls, ceilings and roof. Polystyrene (XPS, EPS) and mineral insulation (rock and glass wool) were used. Materials of surfaces included lime or lime-cement indoor plasters, silicate or silicone external plasters, wide range of floor surfaces (ceramics, laminate, wood, concrete) or gypsum plasterboard used for lower ceiling mostly. Standard doors and windows frames were made of wood or plastic with double or triple glazing. Characterization of materials of assessed houses is presented in table 2.

Table 2: Material composition of assessed buildings

\begin{tabular}{|c|c|c|c|c|c|}
\hline & House H1 & House H2 & House H3 & House H4 & House H5 \\
\hline 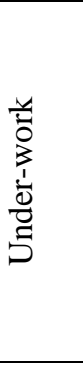 & $\begin{array}{c}\text { concrete } \\
\text { foundations, base } \\
\text { plate - reinforced } \\
\text { concrete, gravel, } \\
\text { PVC foil, } \\
\text { geotextile }\end{array}$ & $\begin{array}{c}\text { concrete } \\
\text { foundations, } \\
\text { concrete base } \\
\text { plate, gravel, } \\
\text { polymer bitumen } \\
\text { sheet }\end{array}$ & $\begin{array}{c}\text { concrete } \\
\text { foundations, } \\
\text { concrete base } \\
\text { plate, concrete } \\
\text { hollow blocks, } \\
\text { gravel, polymer } \\
\text { bitumen sheet, } \\
\text { reinforced } \\
\text { concrete stairs }\end{array}$ & $\begin{array}{c}\text { concrete } \\
\text { foundations, } \\
\text { concrete base } \\
\text { plate, gravel, PVC } \\
\text { foil, geotextile }\end{array}$ & $\begin{array}{l}\text { concrete foundations, } \\
\text { base plate-reinforced } \\
\text { concrete, concrete } \\
\text { hollow blocks, gravel, } \\
\text { aluminum-bitumen } \\
\text { sheet, reinforced } \\
\text { concrete staircase }\end{array}$ \\
\hline 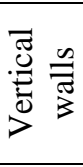 & $\begin{array}{c}\text { perforated } \\
\text { ceramic bricks, } \\
\text { lintels -reinforced } \\
\text { concrete } \\
\end{array}$ & $\begin{array}{c}\text { perforated } \\
\text { ceramic bricks, } \\
\text { lintels-reinforced } \\
\text { concrete } \\
\end{array}$ & $\begin{array}{l}\text { aerated concrete } \\
\text { blocks, lintels, } \\
\text { pillars-reinforced } \\
\text { concrete }\end{array}$ & $\begin{array}{l}\text { aerated concrete } \\
\text { blocks, lintels - } \\
\text { reinforced concrete }\end{array}$ & $\begin{array}{l}\text { perforated ceramic } \\
\text { bricks, lintels, pillars- } \\
\text { reinforced concrete }\end{array}$ \\
\hline 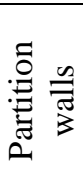 & $\begin{array}{c}\text { perforated } \\
\text { ceramic bricks, } \\
\text { lintels -reinforced } \\
\text { concrete }\end{array}$ & $\begin{array}{c}\text { perforated } \\
\text { ceramic bricks, } \\
\text { lintels -reinforced } \\
\text { concrete }\end{array}$ & $\begin{array}{l}\text { aerated concrete } \\
\text { blocks, lintels - } \\
\text { reinforced } \\
\text { concrete }\end{array}$ & $\begin{array}{l}\text { aerated concrete } \\
\text { blocks, lintels - } \\
\text { reinforced concrete }\end{array}$ & $\begin{array}{l}\text { perforated ceramic } \\
\text { bricks, lintels - } \\
\text { reinforced concrete }\end{array}$ \\
\hline نֶ: & $\begin{array}{l}\text { bond beams- } \\
\text { reinforced } \\
\text { concrete, wood } \\
\text { ceiling, OSB } \\
\end{array}$ & $\begin{array}{l}\text { bond beams- } \\
\text { reinforced } \\
\text { concrete, ceramic } \\
\text { ceiling, concrete } \\
\end{array}$ & $\begin{array}{c}\text { bond beams, } \\
\text { girders-reinforced } \\
\text { concrete, wood } \\
\text { ceiling } \\
\end{array}$ & $\begin{array}{l}\text { bond beams- } \\
\text { reinforced } \\
\text { concrete, wood } \\
\text { ceiling, OSB } \\
\end{array}$ & $\begin{array}{l}\text { bond beams- } \\
\text { reinforced concrete, } \\
\text { wood ceiling, OSB }\end{array}$ \\
\hline 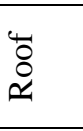 & $\begin{array}{l}\text { wood framework, } \\
\text { ceramic tiles }\end{array}$ & $\begin{array}{l}\text { wood framework, } \\
\text { bitumen sheeting }\end{array}$ & $\begin{array}{l}\text { wood framework, } \\
\text { ceramic tiles, } \\
\text { galvanized sheet }\end{array}$ & $\begin{array}{c}\text { wood framework, } \\
\text { ceramic tiles, steel } \\
\text { sheet }\end{array}$ & $\begin{array}{c}\text { wood framework, } \\
\text { concrete tiles, } \\
\text { galvanized sheet }\end{array}$ \\
\hline
\end{tabular}




\begin{tabular}{|c|c|c|c|c|c|}
\hline 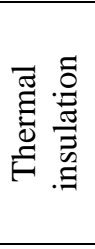 & $\begin{array}{c}\text { XPS } \\
\text { (foundations), } \\
\text { EPS (floors), rock } \\
\text { wool (facade), } \\
\text { glass wool } \\
\text { (ceiling, roof) } \\
\end{array}$ & $\begin{array}{c}\text { XPS } \\
\text { (foundations), } \\
\text { rock wool } \\
\text { (facade, floors, } \\
\text { ceiling) }\end{array}$ & $\begin{array}{l}\text { rock wool (floors, } \\
\text { ceiling, thermal } \\
\text { bridges), XPS } \\
\text { (floors) }\end{array}$ & $\begin{array}{l}\text { EPS (facade, } \\
\text { floors), glass wool } \\
\text { (ceiling) }\end{array}$ & $\begin{array}{l}\text { XPS (foundations), } \\
\text { rock wool (facade, } \\
\text { ceiling), EPS (floors) }\end{array}$ \\
\hline 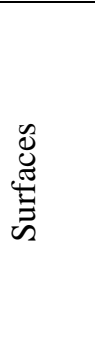 & $\begin{array}{l}\text { concrete screed, } \\
\text { wood floor, } \\
\text { ceramic tiles, } \\
\text { lime cement } \\
\text { plaster, silicate } \\
\text { plaster, glass- } \\
\text { textile mash, } \\
\text { gypsum } \\
\text { plasterboard }\end{array}$ & $\begin{array}{l}\text { concrete screed, } \\
\text { laminate floor, } \\
\text { ceramic tiles, lime } \\
\text { cement plaster, } \\
\text { silicate plaster, } \\
\text { glass-textile mash }\end{array}$ & $\begin{array}{l}\text { concrete screed, } \\
\text { ceramic tiles, } \\
\text { wood logs, wood } \\
\text { floor, concrete } \\
\text { tiles, lime cement } \\
\text { plaster, silicate } \\
\text { plaster, gypsum } \\
\text { plasterboard }\end{array}$ & $\begin{array}{l}\text { concrete screed, } \\
\text { ceramic tiles, } \\
\text { concrete screed, } \\
\text { ceramic tiles, lime } \\
\text { cement plaster, } \\
\text { silicate plaster, } \\
\text { glass-textile mash }\end{array}$ & $\begin{array}{c}\text { concrete screed, } \\
\text { ceramic tiles, wood } \\
\text { paneling, wood floor, } \\
\text { lime cement plaster, } \\
\text { silicate plaster, glass- } \\
\text { textile mash, gypsum } \\
\text { plasterboard }\end{array}$ \\
\hline 贸递 & $\begin{array}{l}\text { wood-aluminum } \\
\text { frame, double } \\
\text { glazed }\end{array}$ & $\begin{array}{l}\text { wood frame, } \\
\text { double glazed }\end{array}$ & $\begin{array}{l}\text { plastic, double } \\
\text { glazed, argon }\end{array}$ & $\begin{array}{l}\text { wood frame, } \\
\text { double glazed, } \\
\text { argon }\end{array}$ & $\begin{array}{l}\text { wood frame, double } \\
\text { glazed, argon }\end{array}$ \\
\hline
\end{tabular}

\subsection{Methodology}

In the study 5 dwellings were analyzed in terms of environmental performance of building materials. For calculation, volumes (areas for some materials) were used for input calculation of weight of materials $(\mathrm{kg})$, embodied energy (primary energy input PEI - MJ), embodied $\mathrm{CO}_{2}$ emissions (global warming potential GWP - $\mathrm{kg} \mathrm{CO} \mathrm{CO}_{2} \mathrm{eq}$ ) and embodied $\mathrm{SO}_{2}$ emissions (acidification potential AP - $\mathrm{kg} \mathrm{SO}_{2} \mathrm{eq}$ ) within cradle to gate boundaries (from extraction of raw materials to leaving of final factory gate). Materials were analyzes as used structures (8 groups: underwork, vertical load bearing walls, partition walls, ceiling, roof, thermal insulation, surfaces and door \& windows). Environmental performance was also evaluated for materials classified into groups upon their manner (11-14 material groups) and overall assessment for whole buildings was also included. Input calculation data of environmental properties were extracted from broadly used database [10-12]. In order to provide the relevant comparison of buildings the normalization of values was performed by transposing calculating the relative values (per $\mathrm{m}^{2}$ or $\mathrm{m}^{3}$ ).

\section{Results}

\subsection{Overall environmental profile}

The total values of assessed parameters calculated according to amount of used materials for particular houses are presented in table 3. 
Table 3: Overall environmental profile

\begin{tabular}{|c|ccccc|}
\hline & H1 & H2 & H3 & H4 & H5 \\
\hline Weight - kg & 238428.7 & 314228.6 & 366986.6 & 175189.2 & 371087.6 \\
PEI - MJ/kg & 2.290 & 1.821 & 1.705 & 2.053 & 2.194 \\
GWP - kg CO 2 eq/kg & 0.130 & 0.139 & 0.100 & 0.060 & 0.110 \\
AP - g SO 2 eq/kg & 0.650 & 0.585 & 0.532 & 0.587 & 0.700 \\
\hline
\end{tabular}

The highest weight of structures, together with the highest AP was reached in house H5 which was one of the largest. The highest PEI was calculated for building H1 and the highest GWP was calculated for house H2. The difference between the lowest and the highest value was $52.8 \%$ of weight (H4-H5), $25.6 \%$ of PEI (H3-H1), even 56.5\% for GWP (H4-H2) and for AP $23.9 \%$ (H3-H5).

\subsection{Environmental performance of particular structures}

For a more precise analysis the materials were classified into structures. Particular parameters were evaluated for each structure to obtain the contribution of particular parts of houses (figure 1).

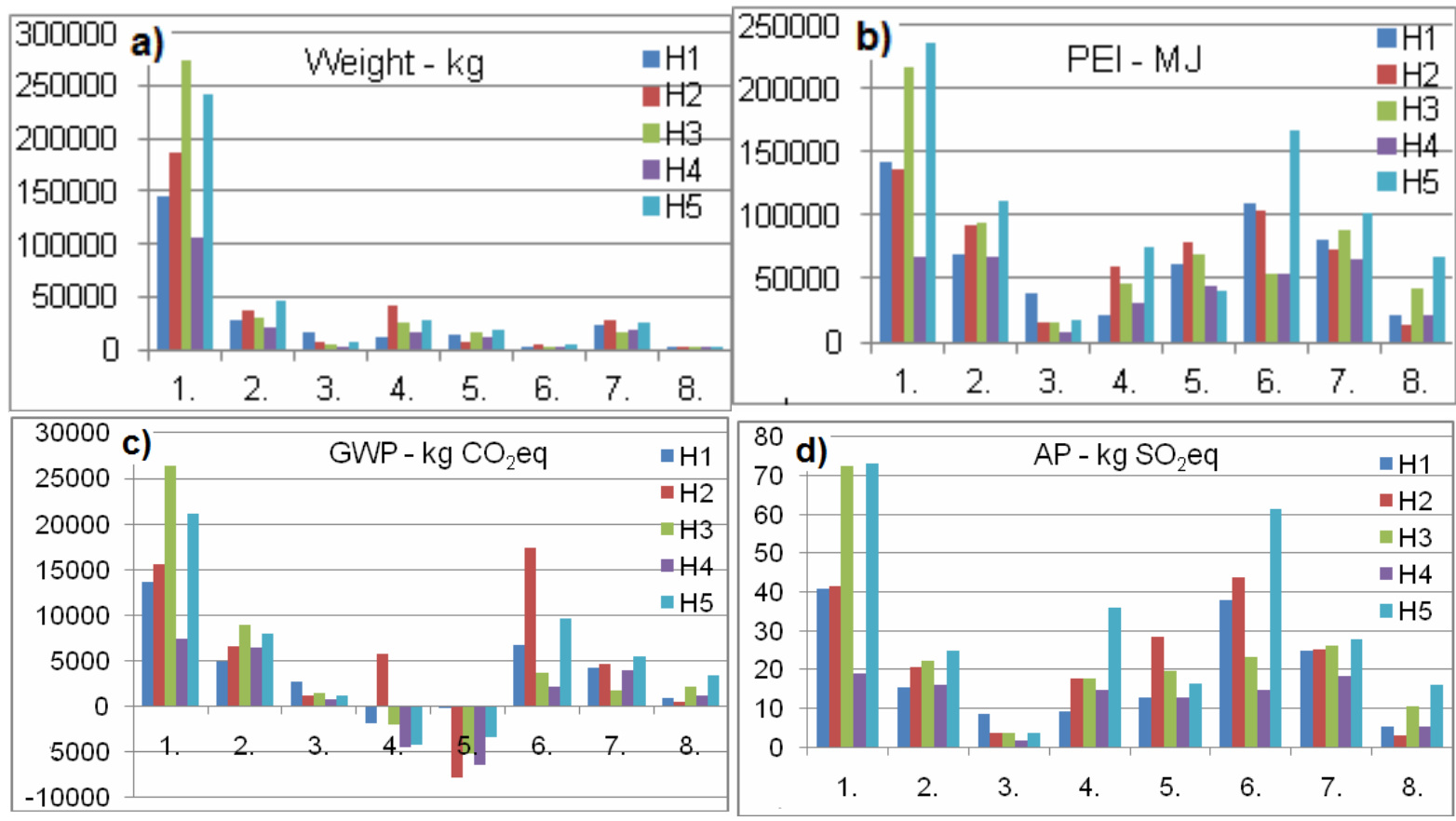

Figure 1: Environmental profile of particular structures (a,-weight, b,-PEI, c,-GWP, d,-AP; 1underwork, 2-vertical load bearing structures, 3-partition structures, 4-ceiling, 5-roof, 6thermal insulation, 7-surfaces, 8-doors \& windows)

As illustrated in figure 1a, the underwork was the heaviest structures in all 5 buildings (105195.0 -272868.6 kg). This was caused due to use of large amount of materials with high 
bulk density (concrete, gravel). Fairly heavy were also the materials of vertical load bearing walls (external as well as internal), which consist of perforated ceramic bricks or aerated concrete blocks with reinforced concrete capping. High level of used materials was calculated for ceiling, particularly in house 2 , in which ceramic ceiling was used unlike wooden ceiling in houses H1, H3-5.

As a result of large quantity of materials for underwork, the highest PEI level (figure 1b) was reached for the same structures (67366.8 - 236134.7 MJ). The exception is vertical load bearing structures of house $\mathrm{H} 4$, in which smaller foundations together with relatively large amount of external and internal walls were used; therefore the highest PEI was calculated for vertical load bearing structures (67964.9 MJ). Relatively high PEI value (ranging from 103695.7 to $167218.1 \mathrm{MJ}$ ) was calculated for thermal insulation especially in houses $\mathrm{H} 1, \mathrm{H} 2$ and $\mathrm{H} 5$, in which high quantity of thermal insulation was used (facade insulation, insulating of foundations, floors, ceiling or roof).

Considering the embodied $\mathrm{CO}_{2}$ emissions, the largest values of GWP were calculated for underwork of and were in range from 7333.7 to $26334.5 \mathrm{~kg} \mathrm{CO}{ }_{2} \mathrm{eq}$ (figure 1c). This was caused by utilization of large amount of concrete and gravel. Relatively high GWP was calculated also for thermal insulation and load bearing walls. Remarkable is the negative contribution of materials of roof in the most of the ceilings (H1, H3-5) to global warming potential. In these structures the large amounts of wood was used, so GWP reached the negative values (-7779.6 to $-169.2 \mathrm{~kg} \mathrm{CO} 2 \mathrm{eq}$ ).

The largest level of AP (figure 1d) was calculated for underwork of houses H3 (AP=72.34 kg $\left.\mathrm{SO}_{2} \mathrm{eq}\right)$ and $\mathrm{H} 5$ ( $\left.\mathrm{AP}=72.34 \mathrm{~kg} \mathrm{SO} \mathrm{S}_{2} \mathrm{eq}\right)$. The second highest contribution to acidification was reached in thermal insulation materials of houses $\mathrm{H} 2$ and $\mathrm{H} 5$ ranging from 43.71 to $61.45 \mathrm{~kg}$ $\mathrm{SO}_{2} \mathrm{eq}$.

\subsection{Environmental performance of particular materials used}

To find out the share of particular building materials group and percentage of its contribution to particular impact category the building materials of each building were divided into groups. Percentage of particular impact categories for house H1 is presented in figure 2.

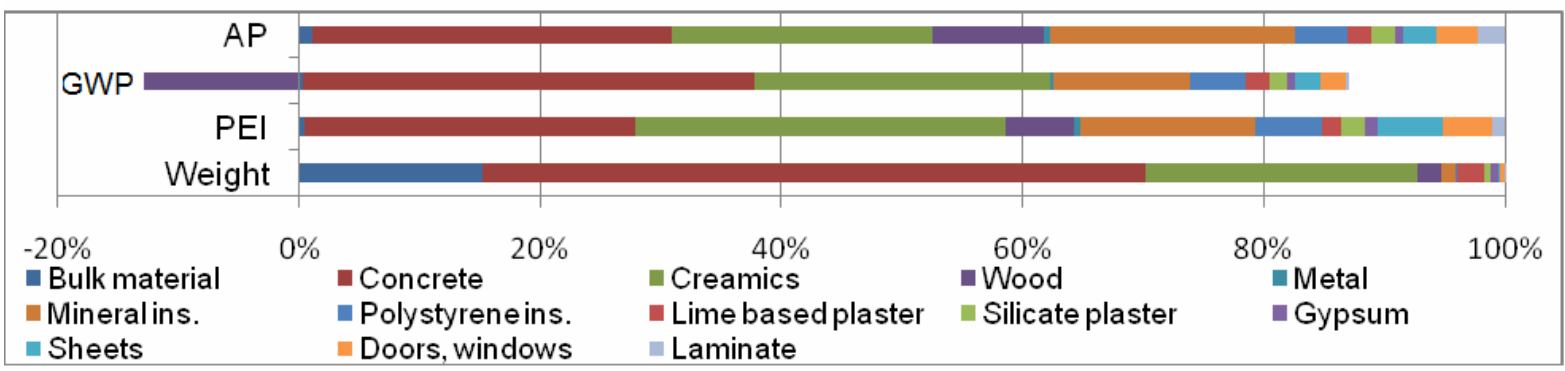

Figure 2: Contribution of building material groups to environmental indicators of house H1

In house $\mathrm{H} 1$ concrete was the material with the largest weight percentage (55\%), while contribution of concrete materials on PEI reached 27.4\%, on GWP 37.4\% and on AP 29.7\%. 
The second heaviest were ceramic structures (bricks, tiles) with $22.5 \%$ of weight. However PEI of ceramics reached the highest value (30.7\%), contribution to GWP reached $24.5 \%$ and contribution to AP reached $21.6 \%$. On the other hand, thermal insulation with relatively light weight (polystyrene $-0.1 \%$, mineral insulation $-1.1 \%$ ) contributed to environmental indicators in substantial way: PEI (polystyrene $-5.6 \%$, mineral insulation $-14.5 \%$ ), GWP (polystyrene $-4.6 \%$, mineral insulation $-11.4 \%$ ) and AP (polystyrene $-4.3 \%$, mineral insulation - 20.3\%). Contribution of wood to GWP reached the negative value $(-12.9 \%)$.

Percentage of contribution of the building materials to particular impact categories of house $\mathrm{H} 2$ is presented in figure 3 .

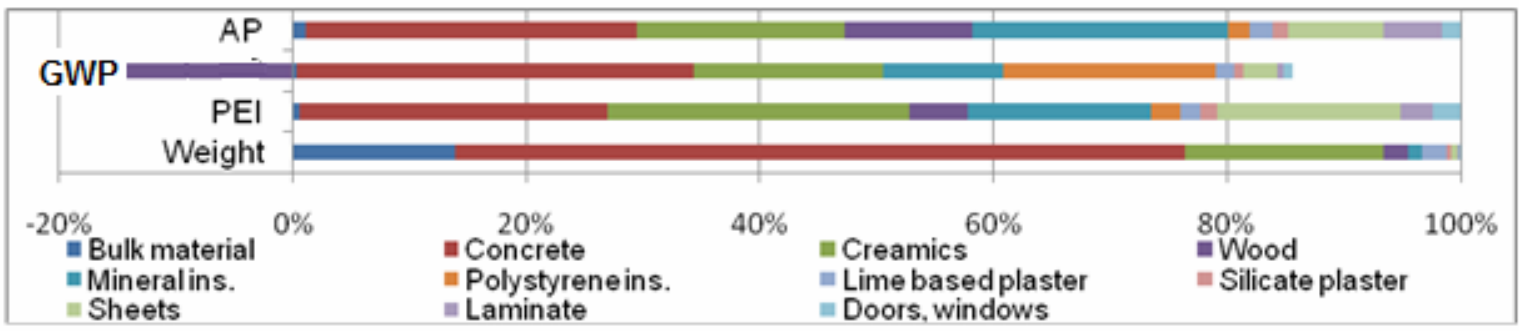

Figure 3: Contribution of building material groups to environmental indicators of house $\mathrm{H} 2$

Concrete materials of house $\mathrm{H} 2$ (figure 3 ) were materials with the highest percenage of weight (62.4\%), PEI with 26.4\%, GWP (34\%) and AP (28.3\%). Ceramics reached the second highest calculated weight (17.1\%) and PEI (25.8\%), the third highest GWP percentage (16.3\%) and AP (17.8\%). Polystyrene was responsible for $18.1 \%$ of GHG emissions and mineral insulation contributed to AP by $21.9 \%$. The negative contribution of wood to GWP reached $-14.4 \%$.

Distribution of environmental indicators of building materials of house H3 are presented in figure 4.

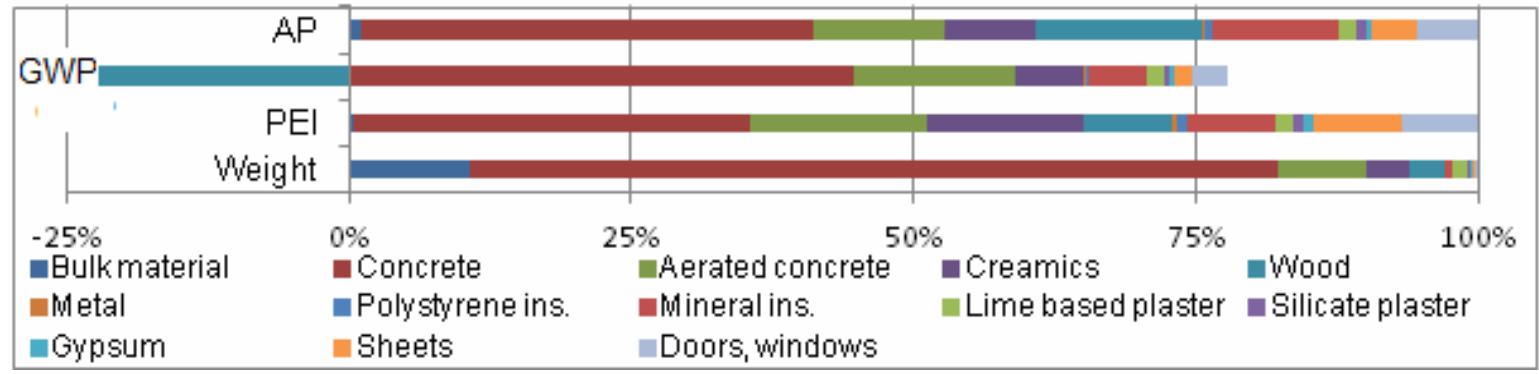

Figure 4: Contribution of building material groups to environmental indicators of house H3

As illustrated in figure 4, concrete was the heaviest (71.8\% of total weight) and was also the one with highest PEI value (35.1\%), GWP (44.5\%) and AP (40.1\%). For this house relatively large negative contribution to GWP $(-22.3 \%)$ was calculated due to intensive use of wood products. 
The share of particular environmental indicators of materials of house $\mathrm{H} 4$ is analyzed in figure 5 .

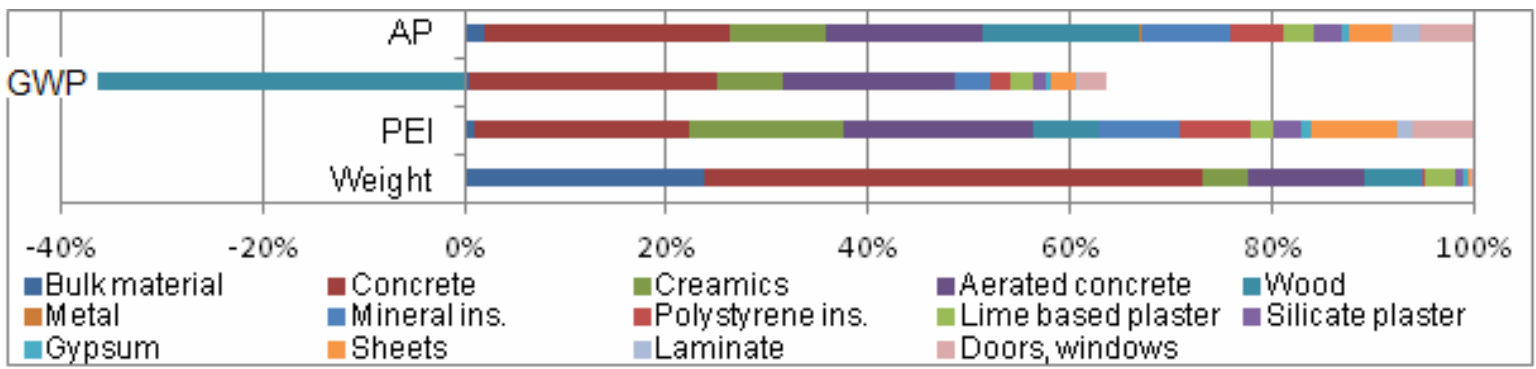

Figure 5: Contribution of building material groups to environmental indicators of house 4

Concrete of house $\mathrm{H} 4$ was evaluated as the heaviest (49.2\% of weight). Concrete was also the material with the highest share of embodied energy (21.3\%), embodied $\mathrm{CO}_{2}$ emisions (24.5\%) and $\mathrm{SO}_{2}$ emissions (24.1\%). A positive fact is the negative value of greenhouse gasses emission of wood materials of roof or celing, which reached $-36.3 \%$ of total $\mathrm{CO}_{2}$ emissions.

Percentage of particular impact categories for house $\mathrm{H} 5$ is presented in figure 6.

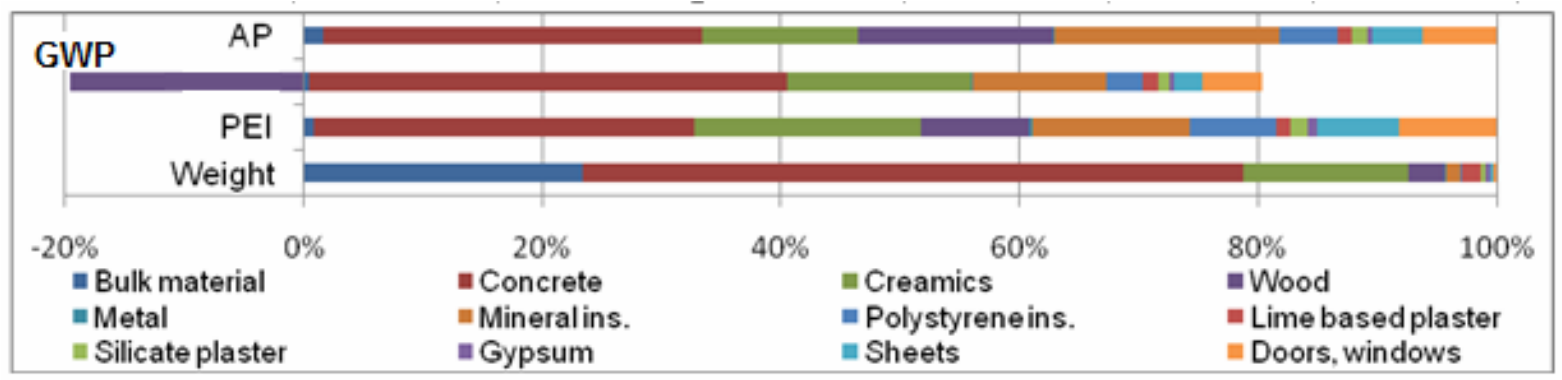

Figure 6: Contribution of building material groups to environmental indicators of house H5

As illustrated in figure 6, the heaviest materials of house $\mathrm{H} 5$ were concrete, bulk and ceramic materials with $55.3 \%, 23.5 \%$ and ) $13.9 \%$ of weight ratio, respectively. The share of concrete on embodied energy reached $31.9 \%$, followed with ceramics $(19 \%)$. The highest amount of $\mathrm{CO}_{2}$ emissions was calculated for concrete materials (40.1\%) and ceramics (15.3\%). Acidification reached the highest level in concrete (31.7\%) followed by mineral thermal insulation (18.8\%). The negative contribution of wood to GWP reached $-19.6 \%$.

\subsection{Normalized environmental performance}

Normalization of total values provides a more precise comparison of particular environmental parameters of various buildings. The total values of environmental performance for particular structures may reach high measure; however normalization per $\mathrm{m} 2$ of particular area or per $\mathrm{m} 3$ of volume offers a more relevant comparison of houses of different size, as presented in table 4. 
Table 4: Normalized environmental profile

\begin{tabular}{|c|ccccc|}
\hline Normalized weight & $\mathrm{H} 1$ & $\mathrm{H} 2$ & $\mathrm{H} 3$ & $\mathrm{H} 4$ & $\mathrm{H} 5$ \\
Build-up area $\left(\mathrm{kg} / \mathrm{m}^{2}\right)$ & 1644.3 & 1978.8 & 1911.9 & 1635.9 & 2039.1 \\
Useful area $\left(\mathrm{kg} / \mathrm{m}^{2}\right)$ & 1952.9 & 2548.9 & 2891.0 & 2187.1 & 2637.6 \\
Living area $\left(\mathrm{kg} / \mathrm{m}^{2}\right)$ & 2943.9 & 4738.1 & 4778.5 & 4018.1 & 4911.8 \\
Build-up cubature $\left(\mathrm{kg} / \mathrm{m}^{3}\right)$ & 364.9 & 489.4 & 419.4 & 288.3 & 433.9 \\
\hline Normalized PEI & $\mathrm{H} 1$ & $\mathrm{H} 2$ & $\mathrm{H} 3$ & $\mathrm{H} 4$ & $\mathrm{H} 5$ \\
Build-up area $\left(\mathrm{MJ} / \mathrm{m}^{2}\right)$ & 3765.2 & 3602.5 & 3259.2 & 3358.6 & 4474.1 \\
Useful area $\left(\mathrm{MJ} / \mathrm{m}^{2}\right)$ & 4471.7 & 4640.4 & 4928.4 & 4490.3 & 5787.5 \\
Living area $\left(\mathrm{MJ} / \mathrm{m}^{2}\right)$ & 6741.0 & 8625.9 & 8145.9 & 8249.4 & 10777.6 \\
Build-up cubature $\left(\mathrm{MJ} / \mathrm{m}^{3}\right)$ & 835.6 & 890.9 & 714.9 & 591.9 & 952.0 \\
\hline Normalized GWP & $\mathrm{H} 1$ & $\mathrm{H} 2$ & $\mathrm{H} 3$ & $\mathrm{H} 4$ & $\mathrm{H} 5$ \\
Build-up area $\left(\mathrm{kg} \mathrm{CO} \mathrm{CO}_{2} \mathrm{eq} / \mathrm{m}^{2}\right)$ & 214.0 & 274.6 & 191.7 & 98.9 & 225.1 \\
Useful area $\left(\mathrm{kg} \mathrm{CO} \mathrm{CO}_{2} \mathrm{eq} / \mathrm{m}^{2}\right)$ & 254.1 & 353.7 & 289.9 & 132.2 & 291.2 \\
Living area $\left(\mathrm{kg} \mathrm{CO} \mathrm{CO}_{2} \mathrm{eq} / \mathrm{m}^{2}\right)$ & 383.1 & 657.5 & 479.2 & 242.8 & 542.2 \\
Build-up cubature $\left(\mathrm{kg} \mathrm{CO}_{2} \mathrm{eq} / \mathrm{m}^{3}\right)$ & 47.5 & 67.9 & 42.1 & 17.4 & 47.9 \\
\hline Normalized AP & $\mathrm{H} 1$ & $\mathrm{H} 2$ & $\mathrm{H} 3$ & $\mathrm{H} 4$ & $\mathrm{H} 5$ \\
Build-up area $\left(\mathrm{kg} \mathrm{SO}{ }_{2} \mathrm{eq} / \mathrm{m}^{2}\right)$ & 1.068 & 1.158 & 1.018 & 0.961 & 1.427 \\
Useful area $\left(\mathrm{kg} \mathrm{SO}{ }_{2} \mathrm{eq} / \mathrm{m}^{2}\right)$ & 1.269 & 1.491 & 1.539 & 1.285 & 1.846 \\
Living area $\left(\mathrm{kg} \mathrm{SO}{ }_{2} \mathrm{eq} / \mathrm{m}^{2}\right)$ & 1.913 & 2.772 & 2.544 & 2.360 & 3.437 \\
Build-up cubature $\left(\mathrm{kg} \mathrm{SO}_{2} \mathrm{eq} / \mathrm{m}^{3}\right)$ & 0.237 & 0.286 & 0.223 & 0.169 & 0.304 \\
\hline
\end{tabular}

Analysis of normalized values of weight, PEI, GWP and AP presented in table 4 and their comparison to total values (table 3 ) reveals the more accurate comparison of buildings when using normalized values, because normalized results provide more relevant measure as it eliminates the size differences of buildings. E.g. in the case of normalization to useful area, the difference between the best and worst alternative reached $32.4 \%$ in the case of weight (H1-H5); $22.7 \%$ in the case of PEI (H1-H5), 62.6\% for GWP (H4-H2) and 31.3\% for AP (H1-H5).

\section{Conclusion}

The selection of suitable building materials is an important factor in building design which requires analysis of wide range of parameters, including environmental ones. In this paper environmental profile of 5 houses was presented with several findings, however they are difficult to be interpreted. The overall environmental impact of materials of underwork and vertical load bearing walls (concrete, ceramic brick etc.) is relatively negative as the total values of PEI, GWP or AP reached the high level due to large amount of used materials. However, also materials with relative low percentage of weight (e.g. thermal insulation) caused led to the negative environmental impacts on global warming or acidification. An important factor is the use of plant materials (wood in this case), which do not contribute to greenhouse gasses emissions and therefore may be one of the possible ways in fulfilling the sustainability strategies. The results of case study have proven that a further investigation in 
the branch of sustainable building is necessary in order to address such a negative impact of building industry.

\section{Acknowledgements}

The research was supported by the project NFP 26220120037 Centre of excellent integrated research of the progressive building structures, materials and technologies and by project VEGA 1/0481/13.

\section{References}

[1] Khasreen, M., Banfill, \& Menzies, G. (2009). Life-Cycle Assessment and the Environmental Impact of Buildings: A Review. Sustainability. 1, 674-701.

[2] Dixit, M. K., Fernandez-Solis, J. L., Lavy, S. \& Culp, C. H. (2010). Identification of parameters for embodied energy measurement: A literature review. Energy and Buildings. 42 (8), 12381247.

[3] Asif, M., Muneer, T. \& Kellery, R (2007). Life cycle assessment: A case study of a dwelling home in Scotland. Building and Environment. 42 (3), 1391-1394.

[4] Metz, B., Davidson, O. R., Bosch, P. R., Dave, R. \& Meyer, L. A. (eds). (2007). Climate Change 2007: Mitigation of Climate Change. Cambridge University Press, Cambridge, UK and New York, USA. June 18，2013. http://www.ipcc.ch/pdf/assessment-report/ar4/wg3/ar4_ wg3_full_report.pdf.

[5] Dutil, Y., Rousse, D. \& Quesada, G. (2011). Sustainable Buildings: An Ever Evolving Target. Sustainability. 3 (2), 443-464.

[6] European Parliament and the Council European Union. (2010). Directive 2010/31/EU of the European Parliament and the Council of 19 May 2010 on the energy performance of buildings. Official Journal of European Union, L153/13-L153/35.

[7] DeBenedetto, L. \& Klemes, J. (2008). LCA as environmental assessment tool in waste to energy and contribution to occupational health and safety. Chemical Engineering Transactions. 13, 343-350.

[8] Culakova, M., Vilcekova, S., Kridlova Burdova, E. \& Katunska, J. (2012). Reduction of Carbon Footprint of Building Structures. Chemical Engineering Transactions. 29, 199-204.

[9] Porhincak, M., Estokova, A. \& Paulikova, A. (2012). Sustainability evaluation of masonry walls using a multi criteria assessment tool. In proc. of 1st International Conference on Building Sustainability Assessment - BSA 2012, May 23-25, 2012 (117-124). Porto, Portugal: Green Lines Institute for Sustainable Development.

[10] Waltjen, T. (ed.). (2009). Passivhaus-Bauteilkatalog. Details for Passive Houses: Okologisch bewertete Konstruktionen. A Catalogue of Ecologically Rated Constructions. Vienna, Austria: Springer.

[11] Kierulf, B. (2008). Ecological Build-up of Energy Passive Houses (in Slovak). In proc. of Passive houses 2008, October 30-31, 2008 (1-6). Brno, Czech Republic: Passive house centre.

[12] Rossi, B, Marique, A-F., Glaumann, M. \& Reiter, S. (2012). Life-cycle assessment of residential buildings in three different European locations, basic tool. Building and Environment. 51, 395-401. 